\title{
Effect of Self-congruity Toward Loyalty With Satisfaction as Intervening Variable in Magnum Consumer in Indonesia
}

\author{
Christina Whidya Utami, Angelia Dwi Lestiyani \\ Widya Mandala Catholic University, Surabaya, Indonesia
}

\begin{abstract}
Brand personality and self-image have a correlation which forms a consumer behavior that may result in satisfaction and loyalty. This research is an modification from Achouri and Bouslama's literature review on 2010. Variables that used in this research are: self congruity as an exogenous variable; satisfaction as an intervening variable; and loyalty as an endogenous variable. This research applying accidental sampling and the sample are 200 “Magnum” consumers in Surabaya, Indonesia. The data were analyzed using Structural Equation Modeling (SEM) method. "Magnum” ice creams are attractive for its consumers, who are mostly women in 17-24 years old, recently graduated from senior high school while some are studying in universities. This research found that self-congruity has positive and significant effect to loyalty through satisfaction.
\end{abstract}

Key words: brand personality, self-image, self-congruity, satisfaction, loyalty

\section{Introduction}

Since the competition between industries becomes tightly and market becomes saturated, producers will try to maintain their market share which is relating to the level of consumer trust to the company. In addition, now consumers have a tendency to make a purchase decision based on attributes and characteristics of a product or brand, called as a brand personality. When consumers make purchase decision, they will associate themselves with the personality of the product. That's why brand personality should be appropriate to the personality of the consumer which is called "self-image".

In 2010, Achouri and Bouslama did a literature review which compared the results of research conducted by previous researchers on the effects of brand personality and self-image on satisfaction and consumer loyalty to a particular brand. Results of this research are the congruence between brand personality and self-image has positive effects on customer satisfaction, consumer attitudes (cognitive loyalty), consumer preferences (emotional loyalty), and also behavioral intentions in the future (conative loyalty). In this study also result that satisfaction has positive effects on consumer attitudes (cognitive loyalty), consumer preferences (emotional loyalty), and behavioral intentions in the future (conative loyalty).

Based on Achouri and Bouslama's research (2010), which is only a literature review that the researcher wanted to apply this concept in a quantitative research of a particular brand. Researcher took ice cream products under the brand "Magnum" as an object to be studied. Researcher considered that the development of

Christina Whidya Utami, Doctor, Lecturer at Faculty of Business, Widya Mandala Catholic University.

Angelia Dwi Lestiyani, Student at Magister Management Program, Widya Mandala Catholic University.

Correspondence concerning this article should be addressed to Christina Whidya Utami, Doctor, Faculty of Business, Widya Mandala Catholic University, Surabaya, Indonesia. E-mail: whidyautami@gmail.com. 
ice cream industry in Indonesia is increasing. Based on data from www.harianterbit.com (2004) in Fitrahdini, Sumarwan, and Nurmalina (2010), the level of ice cream consumption per capita in Indonesia is increased by 67\% from 1999 to 2004. Therefore, consumers of ice cream now are not only the group of children, but also teenagers and adult classes. One of the ice creams which is targeting adult class is "Magnum". "Magnum” is a premium brand ice. The type of decision making for this kind of product is limited decision making and brand personality will has important role because of brand personality can improve self-image of the consumer, and it can be one internal information source in a purchase decision. Based on Achouri and Bouslama's research (2010) and also the issues that mentioned above, researcher wanted to analyse the effect of the congruence between brand personality of "Magnum" ice cream and self-image of the consumer (it will be called self-congruity) on consumers satisfaction and loyalty.

\section{Theoretical Background and Hypothesis}

\section{Brand Personality}

Brand personality is the set of human characteristics associated with a brand (Aaker, 1997). Ouwersloot and Tudorica (2001) states that brand personality can be created through advertising, either directly or indirectly. Aaker (1997) found a tool to measure brand personality which is consists of five dimensions of brand personality and well known as "The Big Five". The dimensions are sincerity, excitement, competence, sophistication, and ruggedness.

\section{Self-image}

According to Resermberg (1979) in Achouri and Bouslama (2010), self-image is the overall thoughts and feelings of an individual who describe themselves as an object. Hawkins and Mothersbaugh (2010, p. 428) states that self-image is the totality of the individual's thoughts and feelings that have reference to themselves as an object. Self-image is divided into four: actual self-image, ideal self-image, private self-image, and social self-image.

\section{Self-congruity}

According to Magin et al. (2003), self congruity is congruence between brand personality of a product to the consumer personality (self-image). Congruence between brand personality and self-image or called as a self-congruity can be measured with the model proposed by Sirgy (1982) which uses "The Big Five" for measure both brand personality and self-image. Congruence or differences that occur between brand personality and self-image was measured using the formula:

$$
\sum_{i=1}^{n}\left|B P_{i j}-S I_{i j}\right|
$$

where:

$$
\begin{aligned}
& B P_{i j}=\text { brand personality }(i) \text { from individual }(j) \text {; } \\
& S I_{i j}=\text { self-image }(i) \text { from individual }(j) .
\end{aligned}
$$

\section{Customer Satisfaction}

Engel, Blackwell, and Miniard (2001, p. 172) states that customer satisfaction is an assessment of post-purchase evaluation of the chosen alternative in which at least gives results equal or exceed customer expectations. Customer satisfaction may influence the occurrence of repeat purchases and establish a word-of-mouth communication so that both can be used to measure customer satisfaction. Positive 
post-purchase evaluation or indicates satisfaction is very important in order to maintain customer to keep buying the product from the same company. Experience consuming products or services will establish communication word-of-mouth.

\section{Customer Loyalty}

Customer loyalty describes the willingness of customers to continue to subscribe at a certain company in the long run by buying and using its products and services repeatedly and voluntarily recommending the product to others (Lovelock \& Wirtz, 2007, p. 359). Loyalty will develop following three stages which are cognitive stage, affective stage, and conative stage. According to Achouri and Bouslama (2010), three stages can be used to measure customer loyalty. First, consumers will be loyal to the cognitive aspect, second to affective aspect, and finally the conative aspects (Dharmmesta, 1999).

\section{Effect of Self-congruity to Satisfaction}

According to Hawkins and Mothersbaugh (2010, p. 432), people will try to acquire their ideal self concept or retain their actual self concept. It often involves to purchase decision and consumption of products and services. The relationship between brand personality and self-image which are congruent will affect consumer behavior and satisfaction. This is also confirmed by Chon (1990) in Achouri and Bouslama (2010); Jamal and Goode (2001) which indicates that there is positive relationship between self-congruity with satisfaction.

H1: Self congruity take effects to customer satisfaction on "Magnum” ice cream at Surabaya.

\section{Effect of Customer Satisfaction to Customer Loyalty}

Kotler and Keller (2007, p. 179) states that high satisfaction or pleasure on a particular product will cause any emotional ties to raise a loyalty to the product. Meanwhile, according to Band (1991, p. 80), customer satisfaction is a situation in which the needs, wants, and expectations of customers are met in a transaction and it will result repeat purchases and loyalty.

H2: Customer satisfaction takes effects to loyalty on "Magnum” ice cream at Surabaya.

\section{Effect of Self-congruity to Customer Loyalty Through Customer Satisfaction}

According to Hawkins and Mothersbaugh (2010, p. 432), the congruence between brand personality and self-image will affect satisfaction and the satisfaction also affects to the raise of consumer loyalty or commitment to a particular product or brand.

H3: Self-congruity take effects to loyalty through customer satisfaction on "Magnum" ice cream at Surabaya.

\section{Research Design}

Data are obtained by directly distributing questionnaires to the respondents. In this research using sample of 200 respondents from the population who are "Magnum" ice cream consumers at Surabaya and using non-probability sampling with accidental sampling. The scale used in this study is a Likert scale of 5 points, with the criteria 1 means strongly disagree until 5 means strongly agree. Especially for self-congruity variables which are using data from the difference between the brand personality and self-image will have a value in the range from 0 to 4 . If the value is getting closer to 0 indicates that the brand personality and self-image more congruent, and vice versa. The difference results need to be converted to fit the scale of the data used for the other variables. The result of the conversion value is what will be used for further processing. All of the data will be analyzed using Structural Equation Modeling (SEM). 
Table 1

Conversion Value to Self-Congruity Variable

\begin{tabular}{lll}
\hline Difference between self congruity and self-image & Conversion value & \\
\hline 0 & 5 & Very congruent \\
1 & 4 & Congruent \\
2 & 3 & Netral \\
3 & 2 & Incongruent \\
4 & 1 & Very incongruent \\
\hline
\end{tabular}

\section{Results}

\section{Gender}

Female respondents are more than male respondents with ratio $61.5 \%$ and $38.5 \%$. This phenomenon may be caused by the advertisements of "Magnum" ice cream which use a woman as a model for its advertising and its brand ambassador. Hutagaol, Hubeis, and Soekarto (2010) state that consumers of ice cream are dominated by women.

\section{Age}

The percentage of respondents with an age range of $17-20$ years old is $34.5 \%, 21-24$ years old is $34 \%$, $25-28$ years old is $17 \%$, and age greater than or equal to 29 years old is $14.5 \%$. It shows that the largest consumer of "Magnum" ice cream is dominated by age range 17-24 years old. Hutagaol et al. (2010) state that $55 \%$ of consumers choose Walls ice cream (Magnum is in Walls ice cream group) is dominated by age $<20$ years old which is suitable with their focus target market.

\section{Education}

The majority of respondents are from high school level and from college as their last education. The percentage of respondents with primary education level is $0 \%$, junior high school is $1 \%$, high school education is $55.5 \%$, college (bachelor degree) is $42.5 \%$, and other education (such as master degree) only $1 \%$. This may be due to the target market of "Magnum" ice cream is to middle-up class where the majority of the members have at least high school level as their last education or even more than high school level.

\section{Occupation}

The majority of respondents are students or college students. The percentage of respondents status as a student or college students is $52 \%$, were employed by private is $30.5 \%$, employed is $12 \%$, working in public company is $4 \%$, and the other works (such as lecturers and tutors) is $1.5 \%$. Hutagaol et al. (2010) also states that focus target market of Walls ice cream ("Magnum" is in Walls ice cream group) is for students ages.

\section{Validity Test}

The data are considered as a valid data if the results of the regression weights have a value of $P$ is less than 0.05 (for the 5\% significance) or $P$ value less than 0.10 (for $10 \%$ significance). The results of validity test can be seen in Table 2 which note that all indicators are valid because its $P$ values are lower than 0.1 (using the $10 \%$ significance). 
Table 2

Results of Validity Test

\begin{tabular}{lll}
\hline Indicator & Significance probability $(P)$ & \\
\hline$X_{1.1}$ & 0.000 & Valid \\
$X_{1.2}$ & 0.000 & Valid \\
$X_{1.3}$ & 0.000 & Valid \\
$X_{1.4}$ & 0.002 & Valid \\
$X_{1.5}$ & 0.000 & Valid \\
$Y_{1.1}$ & 0.000 & Valid \\
$Y_{1.2}$ & 0.000 & Valid \\
$Y_{2.1}$ & 0.000 & Valid \\
$Y_{2.2}$ & 0.000 & Valid \\
$Y_{2.3}$ & 0.000 & Valid \\
\hline
\end{tabular}

\section{Reliability Test}

The method used to calculate the reliability of the instrument is the construct reliability index. Limit values to assess the level of reliability is 0.7 . If the value of CR (construct reliability) is greater than 0.7 then constructs are considered as reliable. The formula used to calculate the construct reliability is:

$$
\text { Construct Reliability }(\mathrm{CR})=\frac{\left(\sum \text { standard loading }\right)^{2}}{\left(\sum \text { standard loading }\right)^{2}+\sum \text { measurement error }}
$$

Table 3

Standard Loading and Measurement Error

\begin{tabular}{llll}
\hline Indicator & Standard loading $(\lambda)$ & Standard loading quadratic $(\lambda)^{2}$ & Measurement error $(1-\lambda)^{2}$ \\
\hline$X_{1.1}$ & 0.438 & 0.1918 & 0.8082 \\
$X_{1.2}$ & 0.714 & 0.5098 & 0.4902 \\
$X_{1.3}$ & 0.418 & 0.1747 & 0.8253 \\
$X_{1.4}$ & 0.355 & 0.1260 & 0.8740 \\
$X_{1.5}$ & 0.411 & 0.1689 & 0.8311 \\
$Y_{1.1}$ & 0.720 & 0.5184 & 0.4816 \\
$Y_{1.2}$ & 0.713 & 0.5084 & 0.4916 \\
$Y_{2.1}$ & 0.710 & 0.5041 & 0.4959 \\
$Y_{2.2}$ & 0.836 & 0.6989 & 0.3011 \\
$Y_{2.3}$ & 0.620 & 0.3844 & 0.6156 \\
Total & 5.935 & & 6.2146 \\
\hline
\end{tabular}

$$
C R=\frac{(5.935)^{2}}{(5.935)^{2}+6.2146}=0.85
$$

$C R$ value is 0.85 . Thus, the constructs used in this study are eligible because the $C R$ value is greater than 0.7 so this means that the entire constructs are reliable and acceptable.

\section{Normality Test}

SEM requires normally distributed data. Data will be said to be normally distributed if the number of critical kurtosis ratio is in the range of -2.58 to +2.58 for a significance level of $10 \%$ or 0.01 . The results of normality test can be seen in Table 4 . 
Table 4

Results of Normality Test

\begin{tabular}{lllrrrr}
\hline Variable & min & max & skew & \multicolumn{1}{c}{ c.r. } & kurtosis & c.r. \\
\hline$Y_{2.1}$ & 1.000 & 5.000 & -0.725 & -4.187 & 0.160 & 0.463 \\
$Y_{2.2}$ & 1.000 & 5.000 & -0.343 & -1.978 & 0.649 & 1.872 \\
$Y_{2.3}$ & 1.000 & 5.000 & 0.031 & 0.176 & -0.374 & -1.079 \\
$Y_{1.2}$ & 1.000 & 5.000 & -0.570 & -3.290 & 0.896 & 2.586 \\
$Y_{1.1}$ & 1.000 & 5.000 & -0.265 & -1.529 & -0.159 & -0.459 \\
$X_{1.5}$ & 1.000 & 5.000 & -1.005 & -5.801 & 1.327 & 3.831 \\
$X_{1.4}$ & 1.000 & 5.000 & -0.651 & -3.759 & 0.298 & 0.859 \\
$X_{1.3}$ & 2.000 & 5.000 & -0.561 & -3.238 & 0.234 & 0.675 \\
$X_{1.2}$ & 2.500 & 5.000 & -0.626 & -3.617 & 0.250 & 0.721 \\
$X_{1.1}$ & 2.000 & 5.000 & -0.767 & -4.426 & 1.063 & 3.070 \\
Multivariate & & & & & 36.681 & 16.742 \\
\hline
\end{tabular}

Based on Table 4, it can be seen that the value of critical ratio and kurtosis of $X_{1.5}$ and $X_{1.1}$ are beyond the range of -2.58 to +2.58 . Actually, both indicators should be discarded, but the data from these two indicators are still used since the majority of other indicators have a normal distribution. This is also confirmed by the results of $C R$ values which show that the result is 0.85 means that all the indicators are reliable, so that the abnormal distribution of $X_{1.5}$ and $X_{1.1}$ can be ignored.

\section{Structural Models and Structural Equation Analysis}

The next step is the evaluation of the structural model associated with the testing of the relationship between variables in order to answer the hypothesis proposed in this study. The results of the structural model test can be seen in Figure 1.

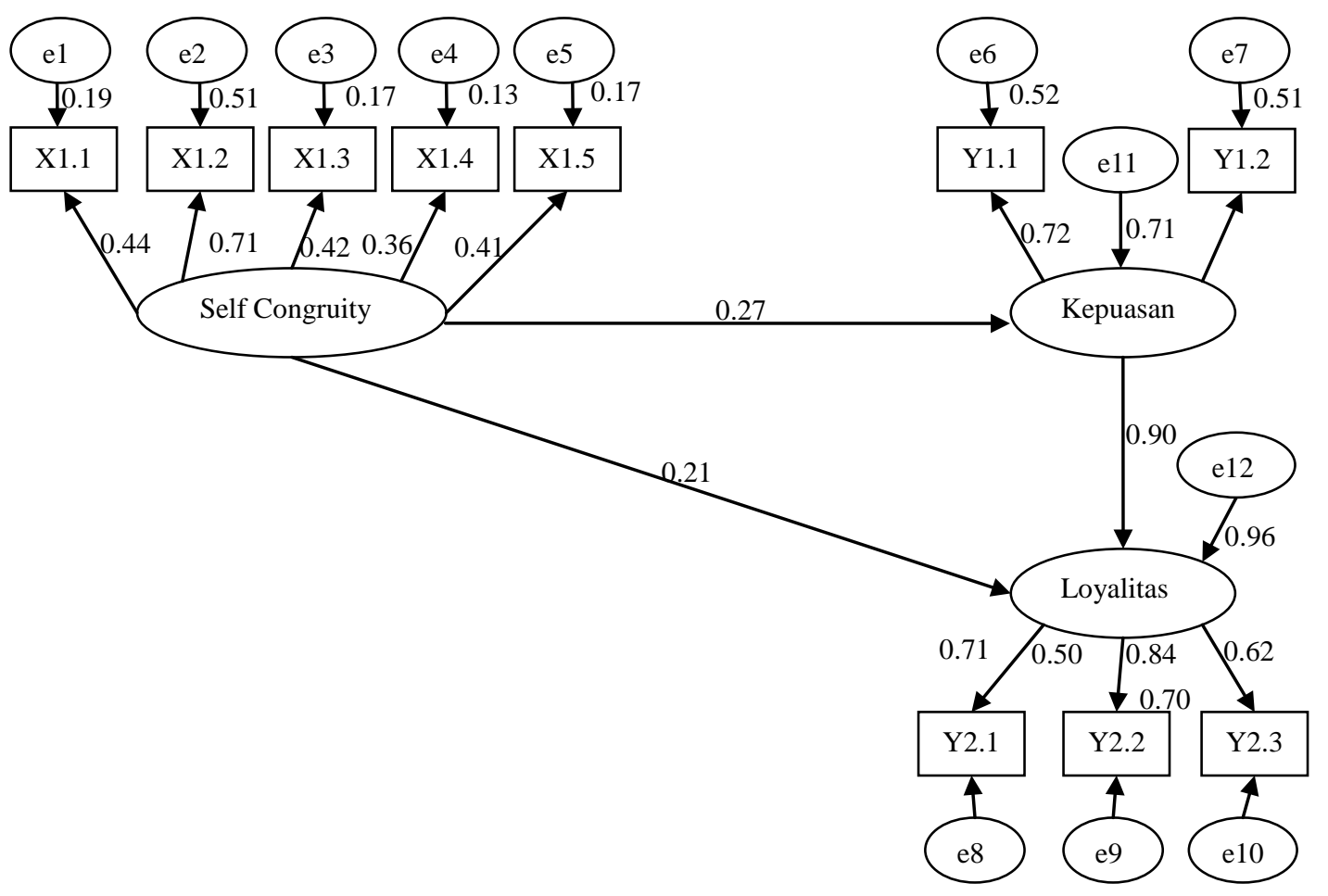

Figure 1. Path analysis results. 
Based on Figure 1, we will obtain standard loading for each individual variable, which can be seen in Table 5.

Table 5

Standard Loading for Each Individual Variable

\begin{tabular}{llll}
\hline Variable & & & Standard loading \\
\hline Self Congruity & $\rightarrow$ & Satisfaction & 0.272 \\
Satisfaction & $\rightarrow$ & Loyalty & 0.903 \\
Self Congruity & $\rightarrow$ & Loyalty & 0.211 \\
\hline
\end{tabular}

Equations generated in this study are the structural equation, because the purpose of this study was to determine the relationship between causality and significant influence variables studied. Structural equations models proposed in this study are as follows:

$$
\begin{gathered}
Y_{1}=0.272 X_{1} \\
Y_{2}=0.903 Y_{1}+0.211 X_{1}
\end{gathered}
$$

In equation (4), self-congruity variable has a positive sign. It indicates that there will be changes in the same direction between self congruity and customer satisfaction with the value of path coefficient is 0.272. While in the equation (5), self-congruity variable and satisfaction variable has a positive sign. It indicates that increasing the customer satisfaction so the customer loyalty will also increase with the value of path coefficient is 0.903 and increasing self-congruity will increase the loyalty with the value of path coefficient is 0.211 .

\section{Goodness of Fit Test}

Goodness of fit test in this research can be seen in Table 6 .

Table 6

Goodness of Fit Test

\begin{tabular}{llcl}
\hline Goodness of fit index & Criteria & Result & Evaluation \\
\hline Chi-Square & $<42.585(p=10 \%, d f=32)$ & 66.367 & Not fit \\
Significant Probability & $\geq 0.05$ & 0.000 & Not fit \\
RMSEA & $\leq 0.08$ & 0.073 & Fit \\
GFI & $\geq 0.90$ & 0.944 & Fit \\
AGFI & $\geq 0.90$ & 0.904 & Fit \\
CMIN/DF & $\leq 2.00$ & 2.074 & Marginal \\
TLI & $\geq 0.95$ & 0.899 & Not fit \\
CFI & $\geq 0.95$ & 0.928 & Marginal \\
\hline
\end{tabular}

\section{Hypothesis Test}

To determine whether causality hypothesis from each variable of this research can be accepted or rejected, it can be seen in Table 7.

Table 7

Hypothesis Test

\begin{tabular}{lllllll}
\hline Variable & & & Estimates & CR & $P$ & \\
\hline Self Congruity & $\rightarrow$ & Satisfaction & 0.272 & 2.360 & 0.018 & Significance \\
Satisfaction & $\rightarrow$ & Loyalty & 0.903 & 6.583 & 0.000 & Significance \\
Self Congruity & $\rightarrow$ & Loyalty & 0.211 & 2.237 & 0.025 & Significance \\
\hline
\end{tabular}




\section{Discussion}

\section{Self-congruity Affects Costumer Satisfaction on “Magnum” Ice Cream at Surabaya}

Based on the results obtained shows that self congruity has positive and significant effect to satisfaction with the value of estimates is 0.272 , value of $C R$ is 2.360 and value of significance probability $(P)$ is 0.018 . These results indicate that the better self congruity (more congruence between brand personality and self-image), it can create more satisfaction on "Magnum” ice cream at Surabaya.

Majority of "Magnum" ice cream consumers on the age range of 17-24 years old or older, it classified as teen-adult and still a student or college student. This is appropriate with the focus target market of "Magnum" ice cream which is for students and adults age (Hutagaol et al., 2010). Congruence between the ages of the consumer with "Magnum" ice cream brand personality can lead to increase customer satisfaction. For example, it can be seen from one of the "Magnum" ice cream advertisement that shows the adventure of two people as secret agents to steal "Magnum" ice cream. It is suitable to the target consumer of "Magnum" ice cream who are teen-adults and at this age usually they love something challenging. So, it can be said that "Magnum" ice cream has a brand personality that is fit with the self-image of the consumer so that it can lead to the satisfaction of the consumer.

The results are match with the theory proposed by Hawkins and Mothersbaugh (2010, p. 432) who stated that the congruence between brand personality and self-image can improve or maintain self-image and then there will be a satisfaction because their purchasing process has a contribution to show consumers self-image. It proves that there is a close relationship between self-congruity and satisfaction. The results of this study also support the research that has been done by Jamal and Goode (2001); Chon (1990) in Achouri and Bouslama (2010).

\section{Satisfaction Affects Loyalty on "Magnum” Ice Cream at Surabaya}

Based on the results obtained shows that satisfaction has positive and significant effect to loyalty with the value of estimates is 0.903 , value of $C R$ is 6.583 and value of significance probability $(P)$ is 0.000 . These results indicate that the higher levels of satisfaction then the higher level of loyalty will be gained. The results also indicate that satisfaction is a significant factor in creating loyalty for "Magnum" ice cream products at Surabaya.

Majority of "Magnum" ice cream consumers have age range 17-24 years old, with their occupation is students or college student. Consumers with these characteristics are likely to buy something just for their pleasure because their lives are still depend on their parents so their basic needs are the responsibility of their parents. It causes the consumers with this characteristic will be looking for fun and not because they really need it. "Magnum" ice cream responds their target market wants by bringing up the positioning statement "for pleasure seekers" to indicate that this ice cream is special for people who are pleasure seekers. Pleasure here can be interpreted as a satisfaction in consuming "Magnum" ice cream which is expected that later their consumers will be loyal.

The results are match with the theory proposed by Kotler and Keller (2007, p. 179) who stated that high satisfaction or pleasure on a certain product will cause any emotional ties to create customer loyalty towards the product. Band (1991, p. 80) also states that satisfaction is a situation in which the needs, wants, and expectations of customers can be met either through a transaction that results in repeat purchases and continues 
to create loyalty. From these two statements, it can be seen that there is a close relationship between customer satisfaction with the creation of customer loyalty. The results of this study also support the research that has been done by Magin et al. (2003), Park and Lee (2005), Oliver (1980), and Oliver and William (1983).

\section{Self Congruity Affects Loyalty Through Customer Satisfaction on "Magnum” Ice Cream at Surabaya}

Based on the results obtained show that self congruity has positive and significant effect to loyalty with the value of estimates is 0.211 , value of $C R$ is 2.237 and value of significance probability $(P)$ is 0.025 . These results indicate that the better self congruity (more congruence between brand personality and self-image) then the higher the loyalty for "Magnum" ice cream products at Surabaya will be gained through satisfaction as an intermediate result (intervening variable).

Majority of "Magnum" ice cream consumers are women. This is match with the results of Hutagaol et al. (2010) which said that ice cream consumers are dominated by women. According to Kartajaya's (2003, p. 122) view, if a company wants to be able to "target" the women customer heart so the company should be able to understand their emotions and feelings. It can be seen from the "Magnum" ice cream advertisement which shows a woman who ate "Magnum" ice cream and then she felt like being a princess. Kartajaya (2003, p. 123) states that there are 16 different types of emotions and these advertisements are created to figure out the emotions and feelings of excitement type. Women who generally tend to act based on their emotions and feelings; of course want to feel something which is similar with the advertising and this will be lead to loyalty through satisfaction. Kartajaya (2003, p. 99) also explains that women are have a mother's instinct so if they already loyal to a certain product or brand, they will act like a mother who will always be protector of the product or brand.

The results are match with the theory proposed by Hawkins and Mothersbaugh (2010, p. 432) which stated that the congruence between brand personality and self-image will affect the satisfaction and then the satisfaction will affect loyalty. It can be concluded that the self congruity may be one factor that create costumer loyalty through customer satisfaction as an intermediate result. The results of this study also support the research that has been done by Jamal and Goode (2001), Helgeson and Supphellen (2004), Onkvisit and Shaw (1989), Sirgy and Samli (1985), Phau and Lau (2001), Ambroise (2006), Morschett et al. (2007) in Achouri and Bouslama (2010).

\section{Conclusions}

Self congruity significantly affects customer satisfaction on "Magnum" ice cream products at Surabaya with the value of estimates is 0.272 , value of $C R$ is 2.360 , and value of significance probability $(P)$ is 0.018 . It indicates that the better self congruity, it can create higher the level of satisfaction.

Customer satisfaction significantly affects loyalty on “Magnum” ice cream products at Surabaya with the value of estimates is 0.903 , value of $C R$ is 6.583 , and value of significance probability $(P)$ is 0.000 . It indicates that the higher level of satisfaction, it can gain the higher level of loyalty.

Self congruity significantly affect loyalty through customer satisfaction on "Magnum" ice cream products at Surabaya with the value of estimates is 0.211 , value of $C R$ is 2.237 , and value of significance probability $(P)$ is 0.025 . It indicates that the better self congruity (more congruence between brand personality and self-image) then the higher the loyalty for "Magnum" ice cream products at Surabaya will be gained through satisfaction as an intermediate result (intervening variable). 


\section{References}

Aaker, J. L. (1997). Dimensions of brand personality. Retrieved November 2, 2011, from http://faculty-gsb.stanford.edu/aaker/PDF/Dimensions_of_Brand_Personality.pdf

Achouri, M. A., \& Bouslama, N. (2010). The effect of the congruence between brand personality and self-image on consumer's satisfaction and loyalty: A conceptual framework. Retrieved October 31, 2011, from http://www.ibima publishing.com/journals/IBIMABR/2010/627203/627203.pdf

Ambroise, L. (2006). La Personnalité des Marques: Une Contribution Réelle à Leur Gestion. Revue Française du Marketing, 207(2/5), 25-41.

Assael, H. (2001). Consumer behavior and marketing action (6th ed.). Singapore: Thomson Learning.

Band, W. A. (1991). Creating value for customer: Designing and implementation a total corporate strategy. Canada: John Wiley and Sons, Inc..

Chon, K. S. (1990). Consumer satisfaction and dissatisfaction in tourism as related to destination image perception (Ph.D. dissertation, Virginia Tech University).

Darsono, L. I. (2004). Loyalty and disloyalty: Sebuah pandangan komprehensif dalam analisis loyalitas pelanggan. KINERJA, $8(2), 163-173$.

Dharmmesta, B. S. (1999). Loyalitas pelanggan: Sebuah kajian konseptual sebagai panduan bagi peneliti. Jurnal Ekonomi dan Bisnis Indonesia, 14(3), 73-88.

Durianto, S. D., \& Sitinjak, T. (2001). Strategi menaklukan pasar melalui riset ekuitas dan perilaku merek. Jakarta: PT Gramedia Pustaka Tama.

Engel, J. F., Blackwell, R. D., \& Miniard, P. W. (2001). Consumer behavior (9th ed.). Orlando: Harcourt College Publishers.

Ferdinand, A. (2000). Structural equation modeling dalam penelitian manajemen: Aplikasi model-model rumit dalam penelitian untuk tesis magister dan disertasi doktor. Semarang: BP Universitas Diponegoro.

Fitrahdini, S. U., \& Nurmalina, R. (2010). Analisis persepsi konsumen terhadap ekuitas merek produk es krim. Journal Ilmu Keluarga dan Konsumen, 3(1), 74-81.

Hawkins, D. I., \& Mothersbaugh, D. L. (2010). Consumer behavior building marketing strategy. New York: McGraw-Hill International Edition.

Helgeson, J. G., \& Supphellen, M. (2004). A conceptual and measurement comparison of self congruity and brand personality. International Journal of Market Research, 46(2), 205-233.

Hutagaol, R. E., Hubeis, M., \& Soekarto, S. T. (2010). Kajian strategi pemasaran es krim baltic di pt. balticindo jayafood Jakarta. Manajemen IKM, 5(2), 122-131.

Jamal, A., \& Goode, M. M. H. (2001). Consumers and brands: A study of the impact of self image congruence on brand preference and satisfaction. Marketing Intelligence \& Planning, 19(7), 482-492.

Kartajaya, H. (2003). Marketing in venus. Jakarta: PT. Gramedia Pustaka Utama.

Kotler, P. (2003). Marketing management (11th ed.). New Jersey: Prentice-Hall International Editions.

Lovelock, C., \& Wirtz, J. (2007). Service marketing: People, technology, strategy (6th ed.). New Jersey: Pearson Prentice Hall.

Magin, S., Algesheimer, R., Huber, F., \& Herrmann, A. (2003). The impact of brand personality and customer satisfaction on customer's loyalty: Theoretical approach and findings of a causal analytical study in the sector of internet service providers. Electronic Markets, 13(4), 294-308.

Manurung, D. (2009). Pengaruh kepuasan konsumen terhadap loyalitas merek pada pengguna kartu pra-bayar simpati. Retrieved from November 4, 2011, from http://repository.usu.ac.id/bitstream/123456789/14517/1/09E01117.pdf

Morschett, D., Jara, M., Schramm-Klein, H., \& Swoboda, B. (2007). Retail brand personality as influence factor on store loyalty-An empirical test of an integrative model. Emac Proceedings, CD-ROM.

Nurmalita, M. (2011). Pengaruh pemakaian endorser dalam iklan televisi melalui kepribadian merek dan implikasinya terhadap citra merek pembalut wanita charm. Retrieved November 4, 2011, from http://www.google.co.id/search?q=Merek+dan+Implikasinya+terhadap+Citra+Merek+Pembalut+Wanita+Charm\&ie=utf-8\& oe=utf-8\&aq=t\&rls=org.mozilla:en-US:official\&client=firefox-a

Oliver, R. L. (1980). A cognitive model of the antecedents and consequences of satisfaction decisions. Journal of Marketing Research, 17(4), 460-469.

Oliver, R. L. (1997). Satisfaction: A behavioral perspective on the consumer. Boston: McGraw-Hill.

Oliver, R., \& William, O. B. (1983). The role of involvement in satisfaction process. Advances in Consumer Research, 10(1), 250-255.

Onkvisit, S., \& Shaw, J. J. (1989). Service marketing: Image and branding and competition. Business Horizons, 32(1), 13-18. 
Ouwersloot, H., \& Tudorica, A. (2001). Brand personality creation through advertising. MAXX Working Paper $2001-01$. Retrieved November 4, 2011, from http://arno.unimaas.nl/show.cgi?fid=478

Park, S. Y., \& Lee, E. M. (2005). Congruence between brand personality and self-image, and the mediating roles of satisfaction and consumer-brand relationship on brand loyalty. Retrieved November 4, 2011, from http://www.acrwebsite.org/volumes/display.asp?id=11859

Phau, I., \& Lau, K. C. (2001). Brand personality and consumer self-expression: Single or dual carriageway? Brand Management, $8(6), 428-444$.

Ranaweera, C., \& Prabhu, J. (2003). The influence of satisfaction, trust, and switching barrier on customer retention in continuous purchasing setting. International Journal of Service Industry Management, 14(4), 374-395.

Resemberg, M. (1979). Conceiving the self. New York: Basic Books.

Sirgy, M. J. (1982). Self-concept in consumer behaviour: A critical review. Journal of Consumer Research, 9(3), $287-300$.

Sirgy, M. J. (1986). Using self-congruity and ideal congruity to predict purchase motivation. Journal of Business Research, 13(1), 195-206.

Sirgy, M. J., \& Samli, A. C. (1985). A path analytic model of store loyalty involving self-concept, store image, socioeconomic status and geographic loyalty. The Journal of The Academy of Marketing Science, 13, 265-291.

Sondoh, S. L., Omar, M. W., Wahid, N. A., Ismail, I., \& Harun, A. (2007). The effect of brand image on overall satisfaction and loyalty intention in the context of color cosmetic. Asian Academy of Management Journal, 12(1), 83-107.

Susanto, A. B., \& Wijanarko, H. (2004). Power branding: Membangun merek unggul dan organisasi pendukungnya. Jakarta: Quantum Bisnis dan Manajemen. 